\title{
ARE ONLINE GUEST REVIEWS USEFUL? IMPLICATIONS FOR THE HOTEL MANAGEMENT
}

\author{
Codruța Adina Băltescu ${ }^{1}$
}

\begin{abstract}
The technological progress and the development of communication means are factors that led to major changes in the hotel guests' booking behavior. The official hotel ratings are no longer sufficient in the attempt to book a hotel. The modern consumer is equally interested in the opinions expressed by previous guests. The online reviews reflect assessments based on the travelers' personal experience and gain significant importance for other guests. This article presents an analysis of the accommodation offer located in the central area of Brașov municipality, and a synthesis of the assessments of Romanian and foreign tourists on Booking.com for the analyzed accommodation units. Moreover, considering that online guest reviews are useful both for the future customers (being a barometer of previous consumers' experiences) and also for managers (as an expression of opinions and expectations of guests) a conjoint analysis has been presented. The conjoint analysis explores the importance value of each hotel attribute score based on each individual's ratings on the attributes and overall ratings.
\end{abstract}

KEYWORDS: online reviews, hotel star-classification, hotel attributes, Booking.com, conjoint
analysis.

JEL codes: M20, O33, Z32.

\section{Introduction}

Nowadays, the Internet and electronic communication have generated significant changes in the marketing strategies of accommodation units (Băltescu and Boșcor, 2015). Technology allows the producer to have a close relationship with the buyer and to use personalization strategies for a large number of customers (Boșcor, 2015). In the age of the Internet, both hotels and their customers (hotel guests) have access to an unlimited amount of information which they can use to their advantages. Hotels could advertise favorable reviews they received and improve on their weaknesses by seriously considering customers' negative comments (Rhee and Yang, 2015). The companies in the hospitability field must be aware of the need to approach the customer, the need to build a long-term relation with this one; moreover, the classical communication modalities are no longer relevant in achieving this goal. (Chițu and Albu, 2013).

To minimize this risk of choosing a hotel, travelers often rely on official hotel ratings to gain insights into hotel quality criteria, as established by official bodies (e.g. National Tourist Offices) and assessed by trained inspectors (Ekinci, 2008 cited in Casalo et al, 2015). The classification of accommodation units consists in assigning certain categories by type, facilities and services and represents an encoded analitical form comprising the level of comfort and the services offered (Lupu, 2010). Yet hotel rating schemes do not reflect any universal quality standards but rather are determined by the official bodies, which implies that they might not reflect travelers' needs and preferences for hotels. Therefore, online reviews have become an important information source that allow consumers to search for detailed and reliable information by sharing past consumption experiences (Yoo and Gretzel, 2008).

\footnotetext{
${ }^{1}$ Faculty of Economic Sciences and Business Administration, Transilvania University of Braşov, România, Email: codruta.baltescu@unitbv.ro
} 
Although international organizations have recommended the alignment of the existing classification systems, the realities demonstrate the impossibility of achieving this objective. In Europe there are approximately 30 classification systems which use different means of expression, namely stars, letters, crowns, comfort level, etc. (ECC-Net, 2009). Within this framework confusions are frequent and another major deficiency is that it does not reflect the experience acquired by visitors after consumption.

One of the most present issues related to the content of classification systems refers to introducing customers' opinions as elements in the assessment and classification of accommodation establishments. This is a new issue, which appeared together with the TripAdvisor revolution. The World Tourism Organization (UNWTO) in collaboration with the Norwegian Accreditation (NA) has conducted and published in July 2014 an analysis regarding the integration of online guest reviews in the existing classification systems (UNWTO, 2014). This document also reveals the fact that before booking, consumers consult, on the average, 14 travel sites, with three visits for each site. For these customers, the classification systems are an important search filters, but the final selection of the accommodation unit is determined by the online guest reviews. UNWTO welcomes the idea that these online reviews issued through independent and well-designed systems represent reliable information, facilitating customer's choice. At the same time, for the hotel managers these online assessments are an important source of information, very useful in the positioning process against their main competitors.

\section{Literature review}

According to the report by Vlachos (2012, cited in Liu and Park, 2015), about 87 percent of international travellers have used the Internet for planning their trips and 43 percent of them have read reviews by other travellers. The decision to purchase a tourism product is taken as a result of either previous experience or a previous communication (Stăncioiu, 2004). Consumers tend to rely on online comments (a form of e-word of mouth) that allow them to obtain sufficient information and have indirect purchasing experiences so as to reduce their level of perceived uncertainty (Ye et al, 2011). At the same time, is a fact that the more reviews a hotel receives, the better quality of booking it will obtain (Torres et al, 2015).

The indisputable advantage of online communities is the use of a unique language for all types of analyzed and assessed accommodation units, regardless of location on the globe. In this way, comparisons become possible, and the decision process for the tourist is much easier. Based on the guests reviews, stars or points are awarded, and the more positive comments posted about cleanliness, comfort, location, facilities, staff, or value for money, the more stars or points are granted to the respective accommodation unit (Marinescu and Frincu, 2015). The online travel communities and travel agencies have favored the emergence of global assessment alternatives of accommodation units included in the visitors' travel options (Băltescu, 2015b). Through the online platforms, the guests could freely express their staying experiences, whether they are satisfied or not, hoping their opinions would make some differences in hotel service quality (Rhee and Yang, 2015) and the quality of products and services is the basis of sustaining competitive advantages for many companies (Brătucu and Boșcor, 2008). It is worth highlighting that online hotel rating lists are perceived as more useful and more credible when they are published by well-known online travel communities. At the same time, a well-known online travel community or travel agency can increase the perceived credibility and usefulness of online hotel rating lists, prompting consumers to respond more positively or negatively to the information (Casalo et al, 2015).

Hotel guests' expectations and actual experiences on hotel service quality often fail to coincide due to guests' unusually high anticipations, hotels' complete breakdowns in delivering their standard, or the combination of both. Moreover, it is important to recognize that while the abundance of online consumer reviews in travel-related social communities makes it easy for 
travellers to find information, it is difficult for them to process and judge useful information (Liu and Park, 2015).

The guests' expectations and assessments tend to differ to a great extent due to units' official confort level. For the lower overall rating hotels, the rooms attribute is the most important factor because the guests would like to make sure at least a place where they would likely to spend much time is comfortable and up to the standard (Choi and Chu, 2001). Guests who stay at low-rated hotels do not expect too much from hotel management in terms of service. They already know they would not receive outstanding service; instead, they would concentrate on other attributes. For instance, the basic attributes such as value, location, and rooms would be highly appreciated for them (Shanahan and Hyman, 2007).

On the other hand, the guests staying at high-rated hotels would consider rooms to be less important because there are many other factors or amenities they expect from hotels: detailed, delicate service such as complementary chocolates, strawberries, and wines for a special occasion (Rhee and Yang, 2015).

The travel communities represent a valuable source of information for hotel managers to determine the characteristics that lead travelers to prefer them (Casalo, at al, 2015). Hotel managers are faced with a difficult decision regarding which areas of attribute they should concentrate in order to serve customers better. The cleanliness attribute should be a top priority for the 2-star hotel, whereas the value attribute is the critical factor for the 4-star hotel. Also, the attribute of service could be sacrificed for the 2-star hotel, and the attribute of cleanliness could be overlooked for the 4-star hotel (Rhee and Yang, 2015). Sleep quality was evenly significantly considered by quests from both low- and high-rated hotels (Rhee and Yang, 2015). The quality of rooms should be maintained with vigor for the low-rated hotel, while service should be sustained at a high level for the high-rated hotel (Liu et al, 2013).

Hotel managers dispute the difficulties of verifying the authenticity of these online reviews and their lack of objectivity. On the other hand, these data cannot be ignored, as they provide essential information needed in the current activity. In order to overcome all this difficulties, there have been formulated specific analysis methods that could represent important tools for the current management (Rhee and Yang, 2015).

In the same register is noteworthy that UNWTO and QualityMark Norway carried out a study looking at models for incorporating guest reviews into classification systems with a view to providing a service that meets the needs of a wider and more demanding customer base. In this respect all participants have been analyzed, namely customers, hospitality industry and intermediaries and two alternatives were proposed (UNWTO, 2014, 16-18).

The first alternative consists in a fully integrated official classification/star rating and guest review system. This innovative model involves the inclusion of the overall guest review ratings for the hotel as part of the evaluation criteria. A key component of this model is the calibration of the weighting given the guest rating. Central to the evaluation process is how the hotel performs on guest ratings compared to, e.g., a national average for its category. A rating statistically significant above the average could lead to awarding the hotel a higher grading, providing that it meets mandatory criteria for the higher grade; the converse would apply if the hotel fared poorly compared to its peer properties.

The second model, known as the comparative performance - the Switzerland model, consists of two elements: the official hotel classification using the European HotelStar Union system and, displayed separately, the average score from a number of guest reviews rating sites. The guest review rating is additive to the official hotel classification rating and they are displayed separately without integration. The two operate individually and are equally illustrated in all marketing material including online material and the average guest review rating is derived through using an online management reputation/filter company. In addition to the objective elements in the 
hotel being portrayed by the stars awarded, a numerical award displays the subjective elements the quality of the welcome, service and comfort.

\section{Research methodology}

Following Rhee and Yang (2015) recommendation, this article presents a conjoint analysis which is used to produce the importance value of each hotel attribute score based on each individual's ratings on the seven attributes and overall ratings. In other words, each review's overall rating is decomposed into seven different attribute ratings whose relative importance is determined. Based on the results of these studies, hotel managers would realize which attributes, among the seven, are more important than others and what attributes could be intentionally overlooked considering limited resources of their own hotel. The analysis took into accont the guests assessments and reviews selected from Booking.com.

The accommodation units chosen for comparisons are from the same type (hotel and boarding house) and from the same star-classification level - 3-star hotels and 4-star boarding houses. The method is relevant only when there is an important number of guest reviews, thus ensuring the relevance and credibility of the assessments.

\section{Results and Discussions}

The analysis of accommodation units located in the central area of Brașov

Braşov municipality is an important Romanian tourist destination, well known among domestic and foreign visitors especially for the medieval buildings and the Transilvanian traditions. As the most important tourist attractions are concentrated in the central area, the majority of accommodation establishments are located in the same district (tabel 1).

Table 1

\section{The distribution of accommodation units located in the central area of Brașov municipality, by type and comfort categories (number of units)}

\begin{tabular}{|c|c|c|c|c|c|c|}
\hline & $\begin{array}{c}\mathbf{5 -} \\
\text { star }\end{array}$ & $\begin{array}{c}\mathbf{4 -} \\
\text { star }\end{array}$ & $\begin{array}{c}\mathbf{3 -} \\
\text { star }\end{array}$ & $\begin{array}{c}\mathbf{1 -} \\
\text { star }\end{array}$ & $\begin{array}{c}\text { No } \\
\text { stars }\end{array}$ & Total \\
\hline Hotels & 1 & 0 & 9 & 1 & 0 & 11 \\
\hline $\begin{array}{c}\text { Boarding } \\
\text { houses }\end{array}$ & 0 & 5 & 11 & 1 & 0 & 17 \\
\hline Villas & 0 & 2 & 0 & 0 & 0 & 2 \\
\hline Hostels & 0 & 0 & 1 & 2 & 3 & 6 \\
\hline Total & $\mathbf{1}$ & $\mathbf{7}$ & $\mathbf{2 1}$ & $\mathbf{4}$ & $\mathbf{3}$ & $\mathbf{3 6}$ \\
\hline \multicolumn{7}{|c|}{ Source: the author's own research }
\end{tabular}

It can be noticed that despite the reputation and tourist attractivity in the central area of Brașov municipality operates a single 5-star accommodation unit, namely Aro Palace Hotel. There are no 4-star hotels and the majority of accommodation units are represented by the 3-star hotels and boarding houses.

The total number of 36 accommodation facilities operating in the central area of the city includes 976 rooms and the distribution by types of accommodation units is shown in figure 1 . 


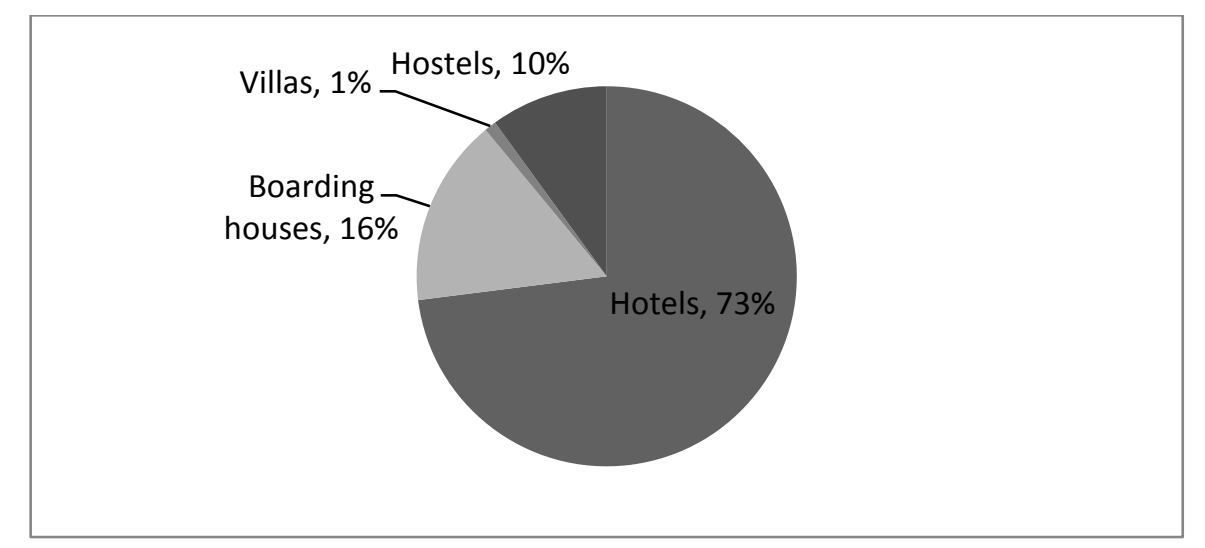

Figure 1. The distribution of rooms by types of accommodation units

Source: the author's own research

Aro Palace Hotel has the largest number of rooms, namely 197 rooms, followed by Capitol Hotel with 183 rooms. The biggest boarding house is Warthe Boarding House (17 rooms) and among hostels, the larger is Casa Dragonilor with 42 rooms.

The analysis of online guest reviews selected from Booking.com for the accommodation units located in the central area of Brașov municipality

The guest reviews selected from Booking.com are evaluated by the following hotel attributes: cleanliness, comfort, location, services, staff, value for money and free Wifi. Every guest gives a note from 1 to 10 to each individual criterion and the final score for each establishment represents the arithmetic media of these notes. Table 2 presents the summary of the scores obtained by the units under analysis.

Table 2

The summary of online guest reviews selected from Booking.com for the accommodation units located in the central area of Brașov municipality

\begin{tabular}{|c|c|c|c|c|}
\hline & $\begin{array}{c}\text { Scores } \\
\text { between 9- } \\
\mathbf{1 0}\end{array}$ & $\begin{array}{c}\text { Scores } \\
\text { between 8-9 }\end{array}$ & $\begin{array}{c}\text { Scores } \\
\text { between 7-8 }\end{array}$ & $\begin{array}{c}\text { Scores } \\
\text { between 6-7 }\end{array}$ \\
\hline Hotels & 2 & 6 & 2 & 1 \\
\hline $\begin{array}{c}\text { Boarding } \\
\text { houses }\end{array}$ & 8 & 6 & 2 & 0 \\
\hline Villas & 1 & 1 & 0 & 0 \\
\hline Hostels & 1 & 3 & 0 & 0 \\
\hline Total & 12 & 16 & 4 & 1 \\
\hline
\end{tabular}

Out of the total number of 36 units only 33 units were analized, as for Kermany \& Dino Boarding House, and for two hostels, namely Dragonilor and Student there were no reviews. It is worth mentioning that $77 \%$ of the analyzed accommodation units have achieved scores above 8 , thus emphasizing the high quality of accommodation services provided and a match between expectations and actual consumption. (figure 2).

The following figure highlights the situation of accommodation units with the higher scores 


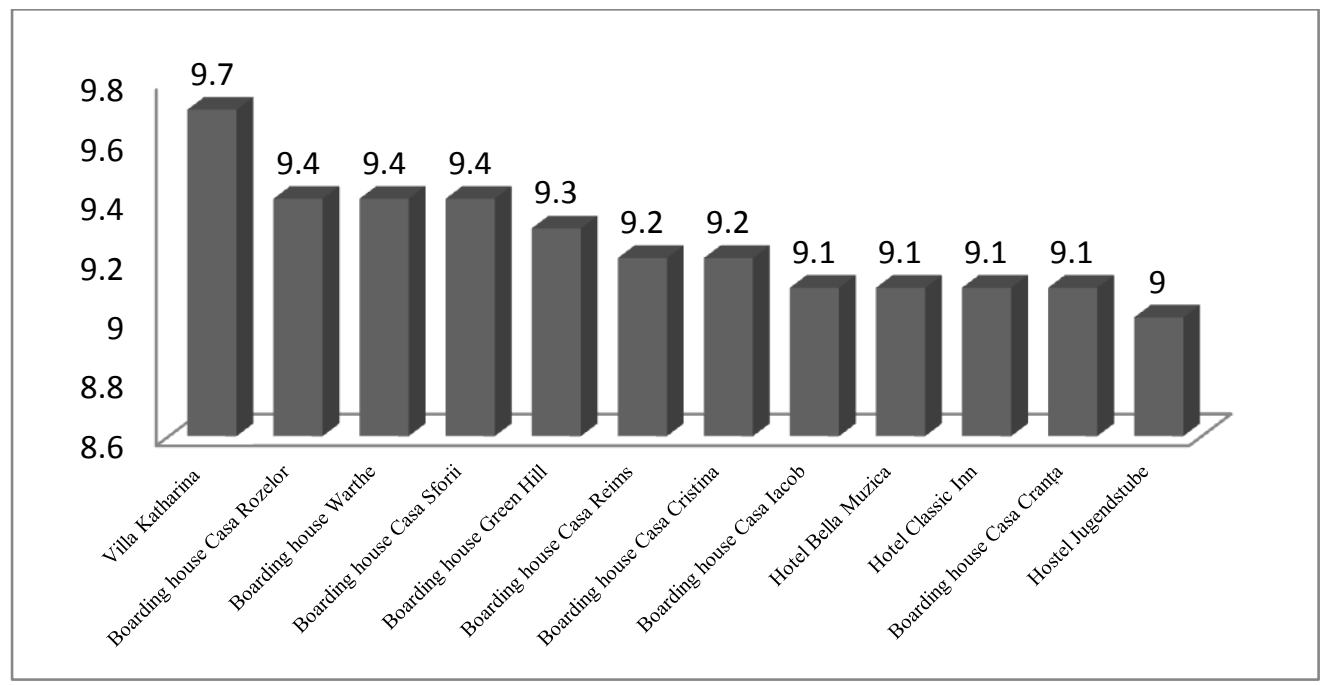

Figure 2. The analysis of total scores obtained in the range 9-10

Source: the author's own research

Villa Katharina has obtained the highest score, 9.7, the boarding houses hostels are highly appreciated by guests and hotels are well represented in this group. The only 5-star hotel in Brasov (Aro Palace) obtained the average score of 8.5.

Hotel attribute importance at an aggregated level and comparisons between hotels and boarding houses

The accommodation units considered for the conjoint analysis are shown in table 3 . These units have been selected as they obtained the most numerous online guest reviews on Booking.com.

The accommodation units included for the conjoint analysis

\begin{tabular}{|c|c|c|}
\hline Accommodation unit & Star-classification & $\begin{array}{c}\text { Total number of online } \\
\text { reviews }\end{array}$ \\
\hline Classic Inn Hotel & 3 & 770 \\
\hline Kolping Hotel & 3 & 787 \\
\hline $\begin{array}{c}\text { Coroana Braşovului } \\
\text { Hotel }\end{array}$ & 3 & 536 \\
\hline Bella Muzica Hotel & 3 & 766 \\
\hline Casa Wagner Hotel & 3 & 1070 \\
\hline $\begin{array}{c}\text { Green Hill Boarding } \\
\text { House }\end{array}$ & 4 & 690 \\
\hline $\begin{array}{c}\text { Casa Cranța Boarding } \\
\text { House }\end{array}$ & 4 & 498 \\
\hline $\begin{array}{c}\text { Casa Reims Boarding } \\
\text { House }\end{array}$ & 4 & 589 \\
\hline
\end{tabular}

Source: the author's own research

The five hotels chosen were analyzed by the comfort category, number of reviews, number of rooms, average price, location and the popularity index on Booking.com (table 4).

Table 4

The description of the analyzed hotels

\begin{tabular}{|c|c|c|c|c|c|}
\hline Description & Classic Inn & Kolping & $\begin{array}{c}\text { Coroana } \\
\text { Brașovului }\end{array}$ & $\begin{array}{c}\text { Bella } \\
\text { Muzica }\end{array}$ & $\begin{array}{c}\text { Casa } \\
\text { Wagner }\end{array}$ \\
\hline Star- & 3 stele & 3 stele & 3 stele & 3 stele & 3 stele \\
\hline
\end{tabular}




\begin{tabular}{|c|c|c|c|c|c|}
\hline classification & & & & & 766 \\
\hline $\begin{array}{c}\text { Number of } \\
\text { reviews }\end{array}$ & 770 & 787 & 536 & 1070 \\
\hline Total score & 9,1 & 8,7 & 8,6 & 9,1 & 8,7 \\
\hline Rooms & 34 & 43 & 42 & 34 & 12 \\
\hline Average price & $70-80 €$ & $50-60 €$ & $50-60 €$ & $60-70 €$ & $50-60 €$ \\
\hline Location & Țibleș nr. 7-9 & $\begin{array}{c}\text { Sandor } \\
\text { Petofi nr. 27 }\end{array}$ & $\begin{array}{c}\text { Piața Unirii nr. } \\
1\end{array}$ & $\begin{array}{c}\text { Piața } \\
\text { Sfatului } \\
\text { nr. 19 }\end{array}$ & $\begin{array}{c}\text { Piața } \\
\text { Sfatului } \\
\text { nr.5 }\end{array}$ \\
\hline $\begin{array}{c}\text { Popularity } \\
\text { index on } \\
\text { Booking.com }\end{array}$ & 5 & 6 & 7 & 19 & 24 \\
\hline
\end{tabular}

Source: the author's own research

Similarly, the three boarding houses chosen for the conjoint analysis were described by the comfort category, number of reviews, number of rooms, average price, location and the popularity index on Booking.com (table 5).

Table 5

The description of the analyzed boarding houses

\begin{tabular}{|c|c|c|c|}
\hline Description & Green Hill & Casa Reims & Casa Cranța \\
\hline $\begin{array}{c}\text { Star- } \\
\text { classification }\end{array}$ & 4 & 4 & 4 \\
\hline $\begin{array}{c}\text { Number of } \\
\text { reviews }\end{array}$ & 690 & 589 & 498 \\
\hline $\begin{array}{c}\text { Total score } \\
\text { Rooms }\end{array}$ & 9,3 & 9,2 & 9,1 \\
\hline $\begin{array}{c}\text { Average } \\
\text { price }\end{array}$ & $30-40 €$ & $50-60 €$ & $70-80 €$ \\
\hline $\begin{array}{c}\text { Location } \\
\text { Str. Dealul } \\
\text { Spirii nr. } \\
\text { 35A }\end{array}$ & $\begin{array}{c}\text { Str. } \\
\text { Castelului nr. } \\
85\end{array}$ & $\begin{array}{c}\text { Str. Maior } \\
\text { Cranta nr.3A }\end{array}$ \\
\hline $\begin{array}{c}\text { Popularity } \\
\text { index on } \\
\text { Booking.com }\end{array}$ & 46 & 27 & 1 \\
\hline
\end{tabular}

Source: the author's own research

The data of all eight hotels and boarding houses were aggregated to generate the importance worth of seven critical hotel attributes (cleanliness, comfort, location, services, staff, value for money and free Wifi.). For Casa Wagner Hotel the attribute of location produced the highest importance worth $(0.161)$, followed by the cleanliness attribute $(0,147)$, while the Wifi attribute's importance showed the lowest worth of 0,131 . The importance worth of the four remaining attributes consisting of staff, comfort and value for money at the same rank, and services was 0,146, 0,139 and 0,137 (table 6).

Table 6

The importance of ranking of hotel attributes

\begin{tabular}{|c|c|c|}
\hline Attribute & Importance & Rank \\
\hline Cleanliness & 0,147 & 2 \\
\hline
\end{tabular}




\begin{tabular}{|c|c|c|}
\hline Comfort & 0,139 & 4 \\
\hline Location & 0,161 & 1 \\
\hline Services & 0,137 & 5 \\
\hline Staff & 0,146 & 3 \\
\hline Value for money & 0,139 & 4 \\
\hline Wifi & 0,131 & 6 \\
\hline
\end{tabular}

Source: the author's own research

The visual results of the attributes' importance worth convey the evenness in the importance of five attributes: location, cleanliness, staff, comfort and value for money (figure 3 ).

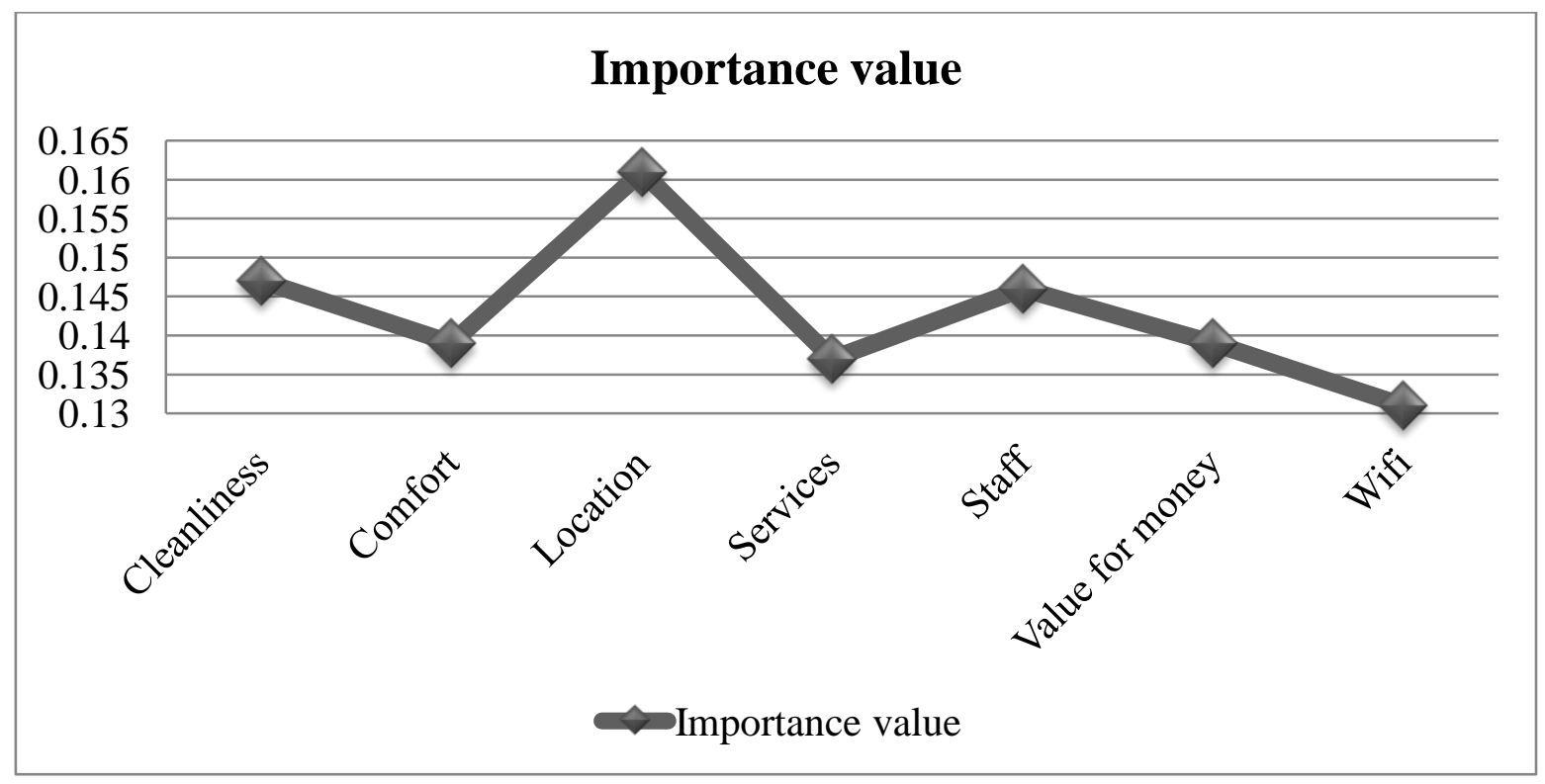

'Figure 3. Hotel attribute importance at an aggregated level (all attributed combined)

Source: the author's own research

The same analyses were performed for each of the accommodation units under examination. Afterwards, comparisons are made at the researcher choice: between different type units, comfort level, or between different combinations of hotel attributes. Figure 4 presents the comparison among the five hotels, all of them being officially classified with 3 stars. 


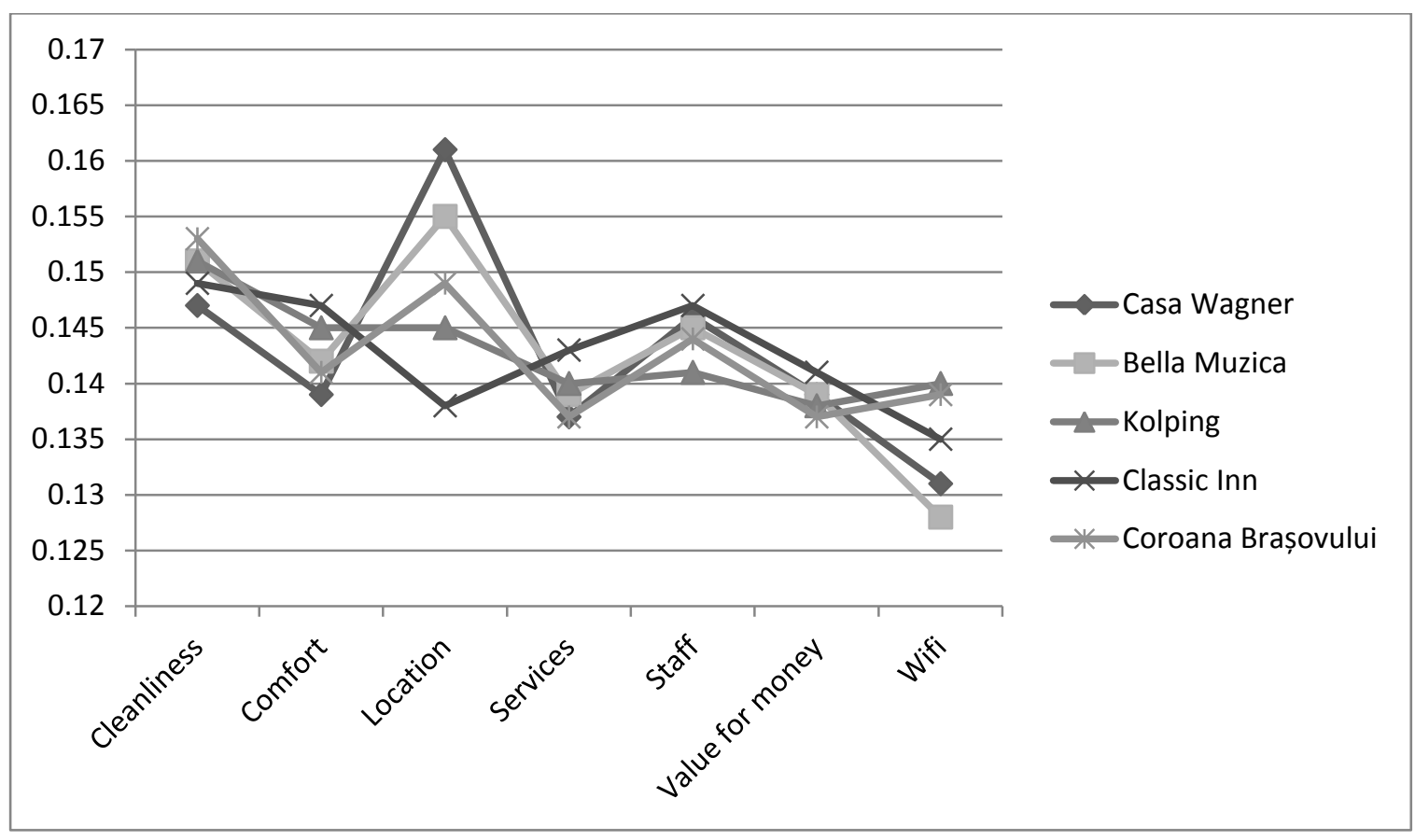

Figure 4. Hotel attributes importance for the five 3-star hotels

Source: the author's own research

\section{Conclusions}

Expanding online communication will influence management and future development of tourism companies' activity. The managers of hotels should not ignore the assessments made by their customers and the remedy of negative aspects reported can be made in due time. The lack of immediate action measures will generate undoubtedly deficiencies with medium and long-term effects (Băltescu, 2015a). Considered irrelevant both by managers, but also by the Romanian tourism authorities, online guest reviews represent a must-do when visitors choose a travel destination or book a hotel. Recent literature highlights that ignoring customer assessments is not a solution, and their analysis is a useful and necessary means to adapt to consumer requests.

The analyses conducted among the accommodation establishments operating in the center area of Brasov highlighted the special attention paid by the management teams on key issues for success, such as impeccable cleanliness, convenient location and friendly staff. Companies that operate in our country should improve their strategy regarding the quality of human resources in order to have proficient future employees (Marinescu, 2006). An overall analysis show the high scores achieved by a significant part of the units surveyed, reflecting managerial concerns in the direction of meeting the needs and expectations of guests.

Based on this information, managers could conceive positioning maps of the units they manage, could analyze the strengths and weaknesses in relation to their competitors, could understand the customers segments, etc. Managers can therefore obtain very useful managerial data. Although there is no longer mandatory, the presence of questionnaires to be filled in by guests could help managers to find appropriate ways to identify the causes of any grievances, which are the justifications for the low notes or rates, and also numerous other little things, but with positive influence on guest reviews. These results also indicate that there are aspects that should be carefully monitored, in order to gain guests' appreciations and loyalty.

In case of negative reviews, responses transmitted in due time play an important role. Customer dissatisfaction could be mitigated by providing explanations, apologies by the hotel 
management in order to recover guests' confidence which in turn will increase the financial performance of the company.

\section{References:}

1. Băltescu, C., A., 2015a. Trends driving the hotel industry global evolution. Case of Romania, Bulletin of the Transilvania University of Brașov, 8(57), No.1, 81-86.

2. Băltescu, C., A., 2015b. The online assessment of tourism services. The hotel market from Brașov County, Bulletin of the Transilvania University of Brașov, 8(57), No.2, 141-148.

3. Băltescu, C.A., Boșcor, D., 2015. The online potential for the development of eco-certified accommodation units in Romania, Bulletin of the Transilvania University of Brașov, 8(57), No.2, 149-156.

4. Boșcor, Dana. 2015. Export strategies adopted by Romanian SME. Bulletin of the Transilvania University of Braşov, 8(57), No.1, 227-232.

5. Brătucu, G., Boșcor, D., 2008. Marketing International. Braşov, Editura Universităţii Transilvania din Braşov.

6. Casalo, L.V., Flavian, C., Guinaliu, M., Ekinci, Y., 2015. Do online hotel ratings schemes influence booking behaviors? International Journal of Hospitality Management, 49, 28-36.

7. Chițu, I.B., Albu, R.G., 2013. Aspects Regarding The Use Of Facebook Within The Hospitality Industry - A Case Study In Romania. Bulletin of the Transilvania University of Braşov, 6(55), No. 1, 97-102.

8. Choi, T. Y., Chu, R., 2001. Determinants of hotel guests' satisfaction and repeat patronage in the Hong Kong hotel industry. International Journal of Hospitality Management, 20(3), 277297.

9. ECC-Net - The European Consumer Centres' Network, 2009. Classification of Hotel Establishments within the AU. Available at http://ec.europa.eu/consumers/ecc/docs/hotel_establishment_classification_EU_en.pdf (7.07.2016).

10. Liu, S., Law, R., Rong, J., Li, G., Hall, J., 2013. Analyzing changes in hotel customers' expectations by trip mode. International Journal of Hospitality Management, 34, 359-371.

11. Liu, Z., Park, S., 2015. What makes a useful online review? Implication for travel product websites. Tourism Management, 47, 140-151.

12. Lupu, N., 2010. Hotelul - economie și management, București, Editura C.H. BECK.

13. Marinescu, N., 2006. Contribuții privind perfecționarea managementului întreprinderilor mici și mijlocii din comerț și turism. Brașov, Editura Universității Transilvania din Brașov.

14. Marinescu, N., Frincu, C., 2015. The Importance of Online Promotion for Tourism SMES." Studia Negotia Universitatis Babeş-Bolyai, 1,15-25.

15. Rhee, H.T., Yang, S.,B., 2015. Does hotel attribute importance differ by hotel? Focusing on hotel star-classifications and customers' overall ratings. Computers in Human Behavior, 50, 2015, 576-587.

16. Shanahan, K. J., Hyman, M. R., 2007. An exploratory study of desired hotel attributes for American tourists vacationing in China and Ireland. Journal of Vacation Marketing, 13(2), 107-118.

17. Stăncioiu, A. F., 2004. Strategii de marketing în turism, Bucureşti, Editura Economică.

18. Torres, E., N., Singh, D., Robertson-Ring, A., 2015. Consumer reviews and the creation of booking transaction value: Lessons from the hotel industry. International Journal of Hospitality Management, 50, 77-83.

19. UNWTO, 2014. Online guest reviews and hotel classification systems. An integrated approach. Available at http://europe.unwto.org/publication/online-guestreviews-and-hotel-classificationsystems-integrated-approach (7.07.2016). 
20. Ye, Q., Law, R., Gu, B., Chen, W., 2011. The influence of user-generated content on traveler behavior: an empirical investigation on the effects of e-word-of-mouth to hotel online bookings. Computers in Human Behavior, 27, 634-639.

21. Yoo, K. H., Gretzel, U., 2008. What motivates consumers to write online travel reviews? Information Technology \& Tourism, 10, 283-295. 